\title{
Maintenance Costs in the Process Industry: A Literature Review
}

\author{
Lemes, Lucas Correa; Hvam, Lars
}

Published in:

Proceedings of the IEEE International Conference on Industrial Engineering and Engineering Management (IEEM)

Link to article, DOI:

10.1109/ieem44572.2019.8978559

Publication date:

2019

Document Version

Peer reviewed version

Link back to DTU Orbit

Citation (APA):

Lemes, L. C., \& Hvam, L. (2019). Maintenance Costs in the Process Industry: A Literature Review. In Proceedings of the IEEE International Conference on Industrial Engineering and Engineering Management (IEEM) (pp. 1481-1485). IEEE. https://doi.org/10.1109/ieem44572.2019.8978559

\section{General rights}

Copyright and moral rights for the publications made accessible in the public portal are retained by the authors and/or other copyright owners and it is a condition of accessing publications that users recognise and abide by the legal requirements associated with these rights.

- Users may download and print one copy of any publication from the public portal for the purpose of private study or research.

- You may not further distribute the material or use it for any profit-making activity or commercial gain

- You may freely distribute the URL identifying the publication in the public portal

If you believe that this document breaches copyright please contact us providing details, and we will remove access to the work immediately and investigate your claim. 


\title{
Maintenance Costs in the Process Industry: a Literature Review
}

\author{
L. C. Lemes ${ }^{1}$, L. Hvam ${ }^{1}$ \\ ${ }^{1}$ Department of Technology, Management and Economics, Technical University of Denmark, Lyngby, Denmark \\ (lucle@dtu.dk,lavh@dtu.dk)
}

Abstract - Maintenance costs in the process industry have changed considerably in the past years due to technological advancements such as increase in automation, Industry 4.0, Big Data, Internet of Things, among others. Cost reduction and modeling are often studied, but related literature lacks the basic indication of common maintenance costs throughout process manufacturing. This paper depicts a literature review on such maintenance costs, defines clusters for easy identification of factors, tries to identify the magnitude of such costs and provides insights on gaps in the literature.

Keywords - Maintenance costs, strategy, literature review, downtime, productivity loss, operations management 


\section{INTRODUCTION}

\section{A. Background}

Maintenance costs in industries can be as high as $40 \%$ of the production costs [1][2] and in some cases even up to $70 \%$ [3]. With recent advances in the industry, increase in the automation and robotics level [4] the boom of Industry 4.0, Big Data and Machine Learning algorithms, maintenance is facing new challenges [5], like increase in automation and complexity and, therefore, labor and repair costs in maintenance can rise.

The urgency of the subject makes it crucial to define the basis for current maintenance costs backed on recent literature and give a clear overview of the reality in the process industry.

The APICS Dictionary determines that companies in the process industry manufacture products by combining, separating, forming, and/or performing chemical reactions [6]. Nakajima defines maintenance costs as a combination of "capital expenditures" and "running costs" related to maintenance [7]. Ashayeri [8] states that process industries have a higher level of automation and a more complicated maintenance function than discrete industries, among other distinctions. Thus, process industries have a relevant differentiation worth analyzing, and their intrinsic characteristics alter the composition of maintenance costs. Furthermore, cost reduction models can profit from such standardization, expanding the theory consolidated in operations management.

To assess the topic relevance within the industrial field, consider company A, a process manufacturer with several plants around the world and a history of acquisitions and capacity expansions. In this scenario, maintenance is historically decentralized unless a thorough initiative had been implemented. The maintenance and production departments are governed separately, each having their own respective cost-center and with a maintenance department 
that is highly technical, corrective-oriented. In such a context, costs are not easily observable, hindering optimal results. If a company cannot clearly overview and classify their own costs, it is hard to take the correct actions to reduce them.

This paper intends on looking at the cost structure within maintenance and describe the basic elements of expenditures at a low-level, which is as close to the actual outlay as possible. In opposition, a high-level cost relates to holistic activities and is usually composed of several low-level costs. For example, in a visual inspection activity, the cost involved might be the wages from technicians performing the work. Thus, "inspection" costs would characterize as high-level in the rank, whereas "wages" will fall in the low-level at the bar. The purpose of the low-level classification presented in this work is to draw a realistic picture of an operational budget and be able to draw useful assumptions for the industry.

Consider predictive maintenance the "proclamation or declaration in advance based on observation to preserve from failure or sustain against danger", corrective as restoration of "an asset to a preserved condition" and preventive as tasks that prolong life of an asset or detect critical wear/failure [9].

Finally, through relevant literature in the field, this article brings a picture of the current state of industry costs.

\section{B. Research Questions}

To keep a clear view of the path to be explored throughout the analysis, a set of questions has been developed and will guide the development of the article:

RQ1 - what maintenance costs does the literature regarding process industries mostly cite?

RQ2 - how to classify these maintenance costs?

RQ3 - how are maintenance costs quantified and what is their magnitude? 


\section{Delimitation}

The presented study focus on heavy industries within the process industry. Special cases microelectronics and pharmaceutics - were deliberately not included in the search string to get a better overview of the heavy process manufacturing literature. The location where the studies were conducted, if mentioned, was noted but not considered as criteria to delimit, so that the investigation considers all possibilities in different environments.

The articles closest to providing a list of costs are Komonen [10] and Archibald et al [11], even though both focus on models rather than on costs themselves.

\section{METHODOLOGY}

Tranfield's [12] systematic literature review approach has been chosen due to its widespread acceptance and usage in operations management [13].

The following criteria have been adopted to select the applicable literature:

\section{A. Date}

The maintenance field has shown a great development after the automation revolution. Only articles published in the past 30 years (before May 2019) were picked for analysis due to the fast evolution of concepts and thorough change in the automation level throughout the industries. 


\section{B. String}

First, the search strings were developed. As part of the concept, the terms "maintenance" and "costs" must be included in either the title, abstract or key words. Next, the process industry was elaborated, taking into consideration that articles might cite specific industries. Only journal articles were elected for the review to maintain the novelty and quality of the theory assessment.

The opted databases were Scopus and Web of Science (WOS), which are the most extensive databases used in literature search tasks and where it is possible to find most of the relevant publications related to maintenance.

TABLE I

ARTICLE SEARCH STRING

\begin{tabular}{ll} 
Database & Search String \\
\hline Scopus & TITLE-ABS-KEY ( maintenance W/3 cost* OR expen* OR outlay ) AND TITLE-ABS-KEY ( \\
& process OR heavy OR glass OR ceramic OR stone OR clay OR metal OR chemical OR \\
& food OR beverage OR textile OR lumber OR wood OR paper W/3 industry OR \\
& manufacturing ) AND LANGUAGE ( english ) AND DOCTYPE ( ar ) AND PUBYEAR > \\
& 1989 AND ( LIMIT-TO ( SRCTYPE, "j" ) ) \\
Web of & (TS=(maintenance NEAR/3 (cost* OR expen* OR outlay)) AND TS=((process OR heavy OR glass \\
Science $\quad$ OR ceramic OR stone OR clay OR metal OR chemical OR beverage OR textile OR lumber OR wood \\
\\
OR paper) NEAR/3 (industry OR manufacturing)) AND LANGUAGE: (English) AND \\
DOCUMENT TYPES: (Article) AND [excluding] DOCUMENT TYPES: ( PROCEEDINGS \\
PAPER ) \\
Timespan: 1990-2019. Indexes: SCI-EXPANDED, SSCI, A\&HCI, CPCI-S, CPCI-SSH, ESCI.
\end{tabular}

Number of articles: 282 articles from Scopus and 156 from Web of Science. 


\section{Quality}

Only articles from publications within the two first quartiles of the Scimago index in 2017 were considered.

Number of articles: 240

\section{Duplicates}

Duplicates found between the Scopus and WOS databases have been eliminated, considering only one of them.

Number of articles: 217

\section{E. Central topic}

After listing the selected articles, the central topic was then classified. In case it didn't fit the context, the article was disregarded. This screening happened once with the abstract (to eliminate outliers) and then after full-text reading. The articles were then assigned relevance levels from 0 to 3 to indicate the level of affinity to the topic, being 0 the least compatible and 3 extremely relevant for the subject. Articles were then read in order of relevance.

After this final screen, the number of articles left with at least an affinity level 1 was reduced to 68 . 


\section{F. Sample size}

The sample of 68 articles is representative to the order of magnitude of the totality. Fig. 1 presents a summary of the process.

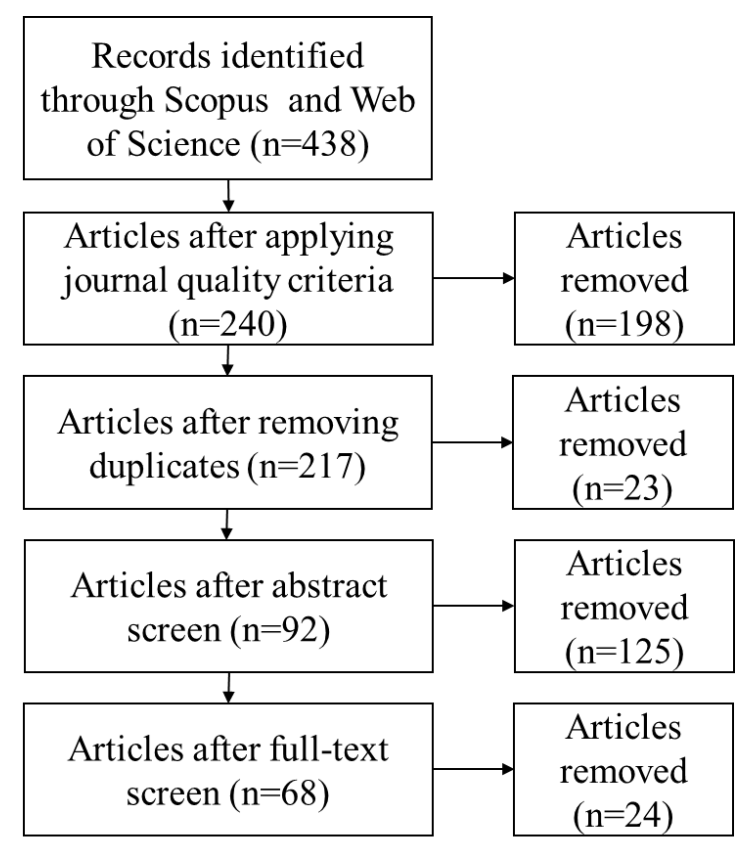

Fig. 1. Article selection tree

It is worth noting that number of citations of the articles was not used in order to obtain an overview even from small case studies, which may be too specific and consequently have a low citation count in the databases. 
MAINTENANCE COSTS AND FAMILIES

\begin{tabular}{|c|c|c|c|}
\hline Nbr. & Costs & Group & Description \\
\hline 1.1 & Downtime & \multirow{5}{*}{$\begin{array}{l}\text { Production } \\
\text { Loss }\end{array}$} & Losses related to period of machine inactivity \\
\hline 1.2 & Setup & & Outlay spent on the setup after a process stop \\
\hline 1.3 & Speed loss & & Difference among equipment's design speed and actual operating speed \\
\hline 1.4 & Quality loss & & Losses in quality caused by defected production equipment \\
\hline 1.5 & Backorder & & Reorder costs for lost production during downtime \\
\hline 2.1 & Salary & \multirow{2}{*}{ Wages } & Outlay spent to pay employees for their work performed \\
\hline 2.2 & Overtime & & Extra expenditure on extra-hours performed \\
\hline 3.1 & $\begin{array}{l}\text { Loss of equipment } \\
\text { life-time }\end{array}$ & \multirow{6}{*}{ Assets } & Reduction of asset value due to misuse or bad service provided \\
\hline 3.2 & Rejuvenation & & Revamping of equipment, adding value to the asset compared to previous condition \\
\hline 3.3 & Degradation & & Natural loss of value due to ageing \\
\hline 3.4 & Upgradation & & Costs to elevate the current state, losing asset's original characteristics and parameters \\
\hline 3.5 & Cleaning & & Housekeeping activities \\
\hline 3.6 & Infra-structure & & Equipment out of production line \\
\hline 4.1 & Spare Parts/Materials & \multirow{3}{*}{ Components } & Components used in a repair, replacement or upgrade \\
\hline 4.2 & Tools & & Devices that support service provided in a repair, replacement or upgrade \\
\hline 4.3 & Consumables & & Products of regular use, such as oil, chemicals, refrigerator liquids, among others \\
\hline 5.1 & Management & \multirow{10}{*}{ Institutional } & Costs attached to the managerial execution, like broadcasting tools, meeting support \\
\hline 5.2 & Logistics & & Any expense related to procurement, transportation, trips, etc. \\
\hline 5.3 & Fiscal/taxes/fees/fines & & Government taxes and legal requirements \\
\hline 5.4 & Insurance & & Contract with insurance company covering any type of risk \\
\hline 5.5 & Safety equipment & & Personal and non-personal safety accessories \\
\hline 5.6 & Training & & Charge for trainings of employees \\
\hline 5.7 & Risk mitigation & & Related to measurements taken before situation occurs \\
\hline 5.8 & Inventory & & Handling costs for spare parts and items in stock \\
\hline 5.9 & Warranty Payments & & Contract breach fees, for example, in case of delivery delays \\
\hline 5.10 & Scraping & & Appropriate allocation of residues \\
\hline 6 & Energy & Energy & Any source of energy used for maintenance activities, plus energy loss \\
\hline 7.1 & Systems & \multirow{2}{*}{ IT } & Dedicated IT software \\
\hline 7.2 & IT Infra-structure & & Dedicated IT hardware \\
\hline 8 & Outsourcing & Outsourcing & Employment of third companies for specific activities \\
\hline
\end{tabular}

\section{RESULTS}

At this point, broader literature - which considers various types of companies and industries - still provides the base for the common costs. It is expected that this study reveal hidden costs that will add to the knowledge. Levitt [9] lists a few general maintenance expenditures and demonstrate that most costs are not explicit, but just like Nakajima [7], they still do not provide a clear picture of the overall budget in the reality, missing systems, taxes and insurance costs, for example.

From the thorough analysis of the selected articles, it was possible to get the abovementioned picture of the costs within the pre-mentioned industrial field. The results are 
summarized in Table II. Aiming to organize and classify the costs, Table II presents the list of costs found in literature, as well as their group and a brief description.

Terms in the list were considered even if not a center topic of the study. In other words, the term should be acknowledged by the article as a maintenance cost. The 5 recurrent costs cited worth highlighting were: wages, downtime, spare parts, consumables and degradation.

Costs listed in Table II were refined not to overlap each other. That means that it is possible to identify unique traits of each cost and clearly segregate them. Take the case of a machine upgrade, for instance. The machinery upgrade is a maintenance activity that is built out of several different costs. To clarify, consider a hypothetical case of machine X, a piece of equipment running for some years in company A. It has reached some level obsolescence and management decided to request the manufacturer of machine $\mathrm{X}$ to turn it into the newest version available, still retaining as much as possible from the original to reduce costs. Mechanical and electrical components will be changed; hence machine parameters will differ from the original. The installation is scheduled for a production stop, so no production loss is considered. A new version of the software is installed and the interface is new. Fig. (2) presents a simplified visual representation of the hypothetical costs. Exact proportions are not presented, since it is not the goal of this explanation.

Notice that there are intrinsic outsourcing costs and upgradation costs. These costs are unique and are not considered in case company A had done the job itself. They are a result of various factors, for example the supplier profit and knowledge capitalization (in outsourcing) and the monetary difference between current and new versions (in upgradation), to name a few. 


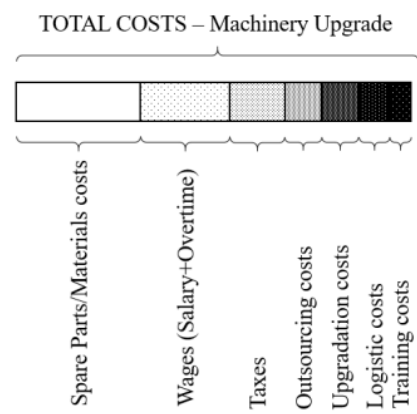

Fig. 2. Hypothetical representation of machinery upgrade costs

Since the presented goal is to rather clarify, shed the light over hidden costs and present a structure for the classification, the costs were treated as equally important in the whole context, and therefore not assigned a value regarding times cited, also because most times terms were solely cited, but not elaborated, creating a fuzzy zone of citation. Moreover, the relevance of each factor varies even within the process industry.

In such a varied selection of articles for review, the respective authors used several terms to designate similar concepts. In this case, the authors of this very paper selected the most relevant recurring terms and integrated others on them. Also, note that those terms are contextualized in maintenance, i.e. they are related to the maintenance activities. For example, when "downtime" is cited, it is the downtime caused by a maintenance stop (may it be corrective, preventive, predictive, and so on), but not the downtime caused by a production stop resulted, for example, from a management decision.

Several models, methods and policies appeared in the selection of 68 articles, which was a good indication of holistic analysis of the industry, implying a good overview of common costs. On the other hand, models tend to oversimplify, considering only a few of the costs shown in Table II. That said, models tend to present cost reduction or cost models without listing the detailed costs. One may say the costs are not extremely relevant for modelling, but it will logically provide a better insight and clarification to the reader when being able to compare with a real situation. 
Whenever articles present the costs, it is rare to see them ranked in order of magnitude. Only Archibald et al. [11] depicts a simplified ranking on replacement costs for corrective maintenance $(\mathrm{R})$ - costs to substitute an equipment in a corrective approach - being higher than replacement costs for preventive maintenance $(\mathrm{P})$ and those higher than corrective repair $(\mathrm{F})$, consequently preventive repair (C). Knowing that predictive costs are lower than preventive ones [14], we can then infer that replacement costs using predictive maintenance $(O)$ and repair costs in predictive maintenance (D), summarized in Eq. (1):

\section{$\mathrm{R}>\mathrm{P}>\mathrm{O}>\mathrm{F}>\mathrm{C}>\mathrm{D}>0$}

Even though the review was limited to the last 30 years, predictive maintenance was curiously commonly disregarded, with less than one-third articles mentioning the predictive approach and mostly superficially. This may be due to the rigorous filter for costs.

The selected articles very seldom mentioned quality and speed losses linked to maintenance. Maintenance has been looked as a necessary evil, rather than a way to reduce costs [8] or as a profit-center [4]. This may help explain why maintenance management often disregards hidden costs, like production losses, when considering maintenance actions. Take company A for instance: managing a cost-driven center, a maintenance manager might focus on optimizing the maintenance budget, meaning that efforts to improve the overall condition of the machine may be overlooked, hence missing a big potential.

Regarding the quantification of maintenance costs, the best analysis in the selection arises from Ghosh [15] in his risk matrix based in the monetary consequence of a failed system, presenting a cost factor for safety, environment, assets and production loss, depending on the magnitude of failure, rather than quantifying for a specific case. Some articles focus on specific equipment; Yan et al. [16] addresses inspection, delay and repair costs for cutters, and costs 
are quantified using his model, though limited to the mentioned costs acquired empirically. In his findings, delay costs grow linearly with time and inspection intervals are optimized to the longest possible, minimizing costs. Vianello [17] presents the costs of desulphurization reactor failure in a chemical industry in the magnitude of US\$800000/day. That said, no clear standard was found within the articles.

\section{CONCLUSION}

The literature on maintenance costs in the process industry have not addressed properly the basic costs, but mostly focused on the correlation between some costs and the development of models. Thus, this gap could hinder the lucidity of models already developed.

Table II introduces a base for classifying maintenance costs, which is the ground for further investigation related to each of these costs, and addresses both RQ1 and 2. Such an overview is important to consider the cross-related impacts in a model and helps closing the previously mentioned gap. The answer to RQ3 is though rather limited, since few articles quantify the costs or propose a real scenario in which major costs are depicted. Thus, it was not possible to find a general magnitude for those costs. Eq. (1) intends to present a basic correlation of the costs magnitude and elaborates the hierarchy showed by [11], expanding the model presented.

In addition, to the best of knowledge, there was no such extensive literature analysis for maintenance expenditures in process industries available in literature, making this study quite relevant for both theory and practice.

Further studies may expand the classification method to other industrial contexts and, consequently, generate a broader overview of costs. Another possible study can focus on the different levels of cost sub-division, since this article is directed, as mentioned, to the lowlevel. 
The quantification of costs throughout the industry, currently rather limited as seen in the results, could help industries accurately assign problems and place themselves within the industry. Several cross-correlations between such costs can build up the ultimate maintenance model.

Table 3 depicts the articles used in the review.

\section{ACKNOWLEDGMENT}

The authors would like to thank the Manufacturing Academy of Denmark (MADE) and the Department of Management at the Technical University of Denmark. 
TABLE III

68 ARTICLES RESULTED FROM DATABASE SEARCH

N. Article

1 Vianello, C., Milazzo, M.F., Maschio, G., Cost-benefit analysis approach for the management of industrial safety in chemical and petrochemical industry, (2019) Journal of Loss Prevention in the Process Industries, pp. 116-123.

2 Kuhnle, A., Jakubik, J., Lanza, G., Reinforcement learning for opportunistic maintenance optimization, (2019) Production Engineering, 13 (1), pp. 33-41.

3 Singh, R.K., Gupta, A., Framework for sustainable maintenance system: ISM-fuzzy MICMAC and TOPSIS approach, (2019) Annals of Operations Research, .

4 Shi, S., Lin, J., Xu, X., Feng, X., Piano, S., Manufacturing-error-based maintenance for high-precision machine tools, (2018) International Journal of Advanced Manufacturing Technology, 95 (1-4), pp. 205-217.

5 Thawkar, A., Tambe, P., Deshpande, V., A reliability centred maintenance approach for assessing the impact of maintenance for availability improvement of carding machine, (2018) International Journal of Process Management and Benchmarking, 8 (3), pp. 318-339.

6 Truong Ba, H., Cholette, M.E., Borghesani, P., Zhou, Y., Ma, L., Opportunistic maintenance considering non-homogenous opportunity arrivals and stochastic opportunity durations, (2017) Reliability Engineering and System Safety, 160, pp. 151-161.

7 Khatab, A., Aghezzaf, E.H., Djelloul, I., Sari, Z., Selective maintenance optimization for systems operating missions and scheduled breaks with stochastic durations, (2017) Journal of Manufacturing Systems, 43, pp. 168-177.

8 Schönmann, A., Dengler, C., Intra, C., Reinhart, G., Lohmann, B., Cycle management of manufacturing resources: identification and prioritization of investment needs, (2017) Production Engineering, 11 (1), pp. 51-60.

9 Pešková, A., Demec, P., Cost modeling for ABC failure of machines, (2017) Manufacturing Technology, 17 (1), pp. $76-79$.

10 Yan, H.-C., Zhou, J.-H., Pang, C.K., Machinery degradation inspection and maintenance using a cost-optimal non-fixed periodic strategy, (2016) IEEE Transactions on Instrumentation and Measurement, 65 (9), art. no. 7478659, pp. 2067-2077.

11 Taylan, O., Kaya, D., Demirbas, A., An integrated multi attribute decision model for energy efficiency processes in petrochemical industry applying fuzzy set theory, (2016) Energy Conversion and Management, 117, pp. 501-512.

12 Haroun, A.E., Maintenance cost estimation: Application of activity-based costing as a fair estimate method, (2015) Journal of Quality in Maintenance Engineering, 21 (3), pp. 258-270.

13 Doostparast, M., Kolahan, F., Doostparast, M., Optimisation of PM scheduling for multi-component systems - A simulated annealing approach, (2015) International Journal of Systems Science, 46 (7), pp. 1199-1207.

14 Savino, M.M., Macchi, M., Mazza, A., Investigating the impact of social sustainability within maintenance operations An action research in heavy industry, (2015) Journal of Quality in Maintenance Engineering, 21 (3), pp. 310-331.

15 Smoczek, J., Szpytko, J., Evolutionary algorithm-based design of a fuzzy TBF predictive model and TSK fuzzy anti-sway crane control system, (2014) Engineering Applications of Artificial Intelligence, 28, pp. 190-200.

16 Meddaoui, A., Bouami, D., Decision making in maintenance using analytical hierarchy process and time-driven activity based costing, (2014) International Journal of Productivity and Quality Management, 13 (4), pp. 450-470.

17 Jawadekar, A., Paraskar, S., Jadhav, S., Dhole, G., Artificial neural network-based induction motor fault classifier using continuous wavelet transform, (2014) Systems Science and Control Engineering, 2 (1), pp. 684-690.

18 Emami-Mehrgani, B., Nadeau, S., Kenné, J.-P., Optimal lockout/tagout, preventive maintenance, human error and production policies of manufacturing systems with passive redundancy, (2014) Journal of Quality in Maintenance Engineering, 20 (4), pp. 453-470.

19 Sa'idi, E., Anvaripour, B., Jaderi, F., Nabhani, N., Fuzzy risk modeling of process operations in the oil and gas refineries, (2014) Journal of Loss Prevention in the Process Industries, 30 (1), pp. 63-73.

20 Wang, L., Machine availability monitoring and machining process planning towards Cloud manufacturing, (2013) CIRP Journal of Manufacturing Science and Technology, 6 (4), pp. 263-273.

21 Xia, T., Xi, L., Zhou, X., Lee, J., Condition-based maintenance for intelligent monitored series system with independent machine failure modes, (2013) International Journal of Production Research, 51 (15), pp. 4585-4596.

22 Markeset, T., Moreno-Trejo, J., Kumar, R., Maintenance of subsea petroleum production systems: A case study, (2013) Journal of Quality in Maintenance Engineering, 19 (2), pp. 128-143.

23 Zhou, X., Lu, Z., Xi, L., Preventive maintenance optimization for a multi-component system under changing job shop schedule, (2012) Reliability Engineering and System Safety, 101, pp. 14-20.

24 Salonen, A., Bengtsson, M., The potential in strategic maintenance development, (2011) Journal of Quality in Maintenance Engineering, 17 (4), pp. 337-350.

25 Qingfeng, W., Wenbin, L., Xin, Z., Jianfeng, Y., Qingbin, Y., Development and application of equipment maintenance and safety integrity management system, (2011) Journal of Loss Prevention in the Process Industries, 24 (4), pp. 321-332.

26 Campos, J.G., Martín, R.M., López, J.S., Quiroga, J.I.A., Machine model-based remote maintenance and fault analysis system for custommade CNC machines, (2010) International Journal of Manufacturing Research, 5 (1), pp. 26-38.

27 Arunraj, N.S., Maiti, J., Risk-based maintenance policy selection using AHP and goal programming, (2010) Safety Science, 48 (2), pp. 238-

28 Ghosh, D., Roy, S., A decision-making framework for process plant maintenance, (2009) European Journal of Industrial Engineering, 4 (1), pp. 78-98.

$29 \mathrm{Hu}, \mathrm{H}$. , Cheng, G., Li, Y., Tang, Y., Risk-based maintenance strategy and its applications in a petrochemical reforming reaction system, (2009) Journal of Loss Prevention in the Process Industries, 22 (4), pp. 392-397.

30 Tsao, Y.-C., Production and payment policies for an imperfect manufacturing system with machine maintenance and credit policies, (2009) International Journal of Technology Management, 48 (2), pp. 240-257.

31 Sachdeva, A., Kumar, D., Kumar, P., Reliability analysis of pulping system using Petri nets, (2008) International Journal of Quality and Reliability Management, 25 (8), pp. 860-877.

32 Sachdeva, A., Kumar, D., Kumar, P., Availability modeling of screening system of a paper plant using GSPN, (2008) Journal of Modelling in Management, 3 (1), pp. 26-39.

33 Freed, T., Doerr, K.H., Chang, T., In-house development of scheduling decision support systems: Case study for scheduling semiconductor device test operations, (2007) International Journal of Production Research, 45 (21), pp. 5075-5093.

34 Kolmetz, K., Ng, W.K., Lee, S.H., Lim, T.Y., Summers, D.R., Soyza, C.A., Optimize distillation column design for improved reliability in operation and maintenance, (2007) Asia-Pacific Journal of Chemical Engineering, 2 (4), pp. 294-307. 
35 Al-Najjar, B., The lack of maintenance and not maintenance which costs: A model to describe and quantify the impact of vibration-based maintenance on company's business, (2007) International Journal of Production Economics, 107 (1), pp. 260-273.

36 Alsyouf, I., The role of maintenance in improving companies' productivity and profitability, (2007) International Journal of Production Economics, 105 (1), pp. 70-78.

37 Al-Najjar, B., Kans, M., A model to identify relevant data for problem tracing and maintenance cost-effective decisions: A case study, (2006) International Journal of Productivity and Performance Management, 55 (8), pp. 616-637.

38 Moore, W.J., Starr, A.G., An intelligent maintenance system for continuous cost-based prioritisation of maintenance activities, (2006) Computers in Industry, 57 (6), pp. 595-606.

39 Gupta, P., Singh, J., Singh, I.P., Maintenance planning based on performance analysis of 7-out-of-14: G chemical system: A case study, (2005) International Journal of Industrial Engineering : Theory Applications and Practice, 12 (3), pp. 266-276.

40 Khan, J.U.R., Zubair, S.M., A risk-based performance analysis of plate-and-frame heat exchangers subject to fouling: Economics of heat exchanger cleaning, (2004) Heat Transfer Engineering, 25 (6), pp. 87-100.

41 Archibald, T.W., Ansell, J.I., Thomas, L.C., The stability of an optimal maintenance strategy for repairable assets, (2004) Proceedings of the Institution of Mechanical Engineers, Part E: Journal of Process Mechanical Engineering, 218 (2), pp. 77-82.

42 Robert, T.P., Shahabudeen, P., Genetic algorithms for cost-effective maintenance of a reactor-regenerator system, (2004) International Journal of Advanced Manufacturing Technology, 23 (11-12), pp. 846-856

43 Al-Ghanim, A., A statistical approach linking energy management to maintenance and production factors, (2003) Journal of Quality in Maintenance Engineering, 9 (1), pp. 25-37.

44 Komonen, K., A cost model of industrial maintenance for profitability analysis and benchmarking, (2002) International Journal of Production Economics, 79 (1), pp. 15-31.

45 Propst, J.E., Doan, D.R., Improvements in modeling and evaluation of electrical power system reliability, (2001) IEEE Transactions on Industry Applications, 37 (5), pp. 1413-1422.

46 Stremersch, S., Wuyts, S., Frambach, R.T., The Purchasing of Full-Service Contracts:: An Exploratory Study within the Industrial Maintenance Market, (2001) Industrial Marketing Management, 30 (1), pp. 1-12.

47 Bhat, V.N., The determinants of maintenance expenditures in chemical companies, (2000) Journal of Quality in Maintenance Engineering, 6 (2), pp. 106-112.

48 Harkonen, Hannu, Taipale, Ville, Life cycle profit calculations for lubrication, (2000) Appita Journal, 53 (1), pp. 10-13.

49 Sarker, R., Haque, A., Optimization of maintenance and spare provisioning policy using simulation, (2000) Applied Mathematical Modelling, 24 (10), pp. 751-760.

50 Jarvis, C., Peck, J., Davis, S., Yu, V., Woszczynski, A., Cost benefit advisor system, (1998) International Journal of Clothing Science and Technology, 10 (6), pp. 76-77.

51 Arts, R.H.P.M., Knapp, G.M., Mann, L., Jr., Some aspects of measuring maintenance performance in the process industry, (1998) Journal of Quality in Maintenance Engineering, 4 (1), pp. 6-11.

52 Al-Sultan, K.S., Al-Fawzan, M.A., Determination of the optimal process means and production cycles for multistage production systems subject to process deterioration, (1998) Production Planning and Control, 9 (1), pp. 66-73.

53 Al-Najjar, B., Total quality maintenance: An approach for continuous reduction in costs of quality products, (1996) Journal of Quality in Maintenance Engineering, 2 (3), pp. 4-20.

54 Ashayeri, J., Teelen, A., Selens, W., A production and maintenance planning model for the process industry, (1996) International Journal of Production Research, 34 (12), pp. 3311-3326.

55 Karabegovic, E., Karabegovic, I., Hadzalic, E., Industrial robot application trend in world's metal industry [Pramoniniu robotu pritaikymo kryptys pasaulineje metalo pramoneje], (2012) Engineering Economics, 23 (4), pp. 368-378.

56 Wiebe, J; Cecilia, I; Misener, R, Data-Driven Optimization of Processes with Degrading Equipment, (2018) INDUSTRIAL \& ENGINEERING CHEMISTRY RESEARCH, 10.1021/acs.iecr.8b03292

57 Liu, YH; Zhang, SM; Ye, XL, A value-based maintenance optimization method for failure prevention based on reliability modeling of a hybrid assembly system, (2018) INTERNATIONAL JOURNAL OF ADVANCED MANUFACTURING TECHNOLOGY, 10.1007/s00170-

58 Xia, TB; Tao, XY; Xi, LF, Operation Process Rebuilding (OPR)-Oriented Maintenance Policy for Changeable System Structures, (2017) IEEE TRANSACTIONS ON AUTOMATION SCIENCE AND ENGINEERING, 10.1109/TASE.2016.2618767

59 Liu, YH; Ye, XL; Ji, FX; Zheng, SL; Jin, S, Dynamic maintenance plan optimization of fixture components for a multistation autobody assembly process, (2016) INTERNATIONAL JOURNAL OF ADVANCED MANUFACTURING TECHNOLOGY, 10.1007/s00170-015-

60 Wang, DJ; Liu, F; Wang, JJ; Wang, YZ, Integrated rescheduling and preventive maintenance for arrival of new jobs through evolutionary multi-objective optimization, (2016) SOFT COMPUTING, 10.1007/s00500-015-1615-7

61 Wang, L; Zhang, L; Wang, XZ, Reliability estimation and remaining useful lifetime prediction for bearing based on proportional hazard model, (2015) JOURNAL OF CENTRAL SOUTH UNIVERSITY, 10.1007/s11771-015-3013-9

62 Golmakani, HR, Condition-based inspection scheme for condition-based maintenance, (2012) INTERNATIONAL JOURNAL OF PRODUCTION RESEARCH, 10.1080/00207543.2011.611540

63 Buyukkamaci, N; Koken, E, Economic evaluation of alternative wastewater treatment plant options for pulp and paper industry, (2010) SCIENCE OF THE TOTAL ENVIRONMENT, 10.1016/j.scitotenv.2010.08.045

64 Chen, Y; Jin, JH, Quality-oriented-maintenance for multiple interactive tooling components in discrete manufacturing processes, (2006) IEEE TRANSACTIONS ON RELIABILITY, 10.1109/TR.2005.864152

65 Krishnasamy, L; Khan, F; Haddara, M, Development of a risk-based maintenance (RBM) strategy for a power-generating plant, (2005) JOURNAL OF LOSS PREVENTION IN THE PROCESS INDUSTRIES, 10.1016/j.jlp.2005.01.002

$66 \mathrm{Kim}, \mathrm{SK}$; Dshalalow, JH, A versatile Stochastic maintenance model with reserve and super-reserve machines, (2003) METHODOLOGY AND COMPUTING IN APPLIED PROBABILITY, 10.1023/A:1024177304981

67 Stremersch, S; Wuyts, S; Frambach, RT, The purchasing of full-service contracts: An exploratory study within the industrial maintenance market, (2001) INDUSTRIAL MARKETING MANAGEMENT, 10.1016/S0019-8501(99)00090-5

68 Rankin, W; Hibit, R; Allen, J; Sargent, R, Development and evaluation of the Maintenance Error Decision Aid (MEDA) process, (2000) INTERNATIONAL JOURNAL OF INDUSTRIAL ERGONOMICS, 10.1016/S0169-8141(99)00070-0 


\section{REFERENCES}

[1] D. M. Maggard, Bill N., Rhyne, "Total productive maintenance. A timely integration of production and maintenance," Prod. Invent. Manag. J. 33(4), pp. 6-10, 1992.

[2] C. R. Vishnu and V. Regikumar, "Reliability Based Maintenance Strategy Selection in Process Plants: A Case Study," Procedia Technol., vol. 25, pp. 1080-1087, 2016.

[3] M. Bevilacqua and M. Braglia, "Analytic hierarchy process applied to maintenance strategy selection," Reliab. Eng. Syst. Saf., vol. 70, no. 1, pp. 71-83, 2000.

[4] I. Alsyouf, "The role of maintenance in improving companies' productivity and profitability," Int. J. Prod. Econ., vol. 105, no. 1, pp. 70-78, Jan. 2007.

[5] R. Roy, R. Stark, K. Tracht, S. Takata, and M. Mori, "Continuous maintenance and the future - Foundations and technological challenges," CIRP Ann. - Manuf. Technol., vol. 65, no. 2, pp. 667-688, 2016.

[6] P. Pittman and J. B. Atwater, APICS Dictionary, 15th Edition. 2016.

[7] S. Nakajima, TPM Development Program: Implementing Total Productive Maintenance. Cambridge, Mass: Productivity Press, 1989.

[8] J. Ashayeri, A. Teelen, and W. Selens, "A production and maintenance planning model for the process industry," Int. J. Prod. Res., vol. 34, no. 12, pp. 3311-3326, 1996.

[9] J. Levitt, Complete Guide to Preventive and Predictive Maintenance, 2nd ed. Industrial Press Inc., 2011.

[10] K. Komonen, "A cost model of industrial maintenance for profitability analysis and benchmarking," Int. J. Prod. Econ., vol. 79, no. 1, pp. 15-31, 2002.

[11] T. W. Archibald, J. I. Ansell, and L. C. Thomas, "The stability of an optimal maintenance strategy for repairable assets," Proc. Inst. Mech. Eng. Part E J. Process Mech. Eng., vol. 218, no. 2, pp. 77-82, 2004.

[12] D. Tranfield, D. Denyer, and P. Smart, "Towards a Methodology for Developing Evidence-Informed Management Knowledge by Means of Systematic Review,” 2003.

[13] C. Karlsson, Research Methods for Operations Management, 2nd ed. Routledge, 2016.

[14] A. Van Horenbeek and L. Pintelon, "A joint predictive maintenance and inventory policy," Lect. Notes Mech. Eng., vol. 19, pp. 387-399, 2015.

[15] D. Ghosh and S. Roy, “A decision-making framework for process plant maintenance," Eur. J. Ind. Eng., vol. 4, no. 1 , p. 78 , Dec. 2009.

[16] H. C. Yan, J. H. Zhou, and C. K. Pang, "Machinery degradation inspection and maintenance using a cost- 
optimal non-fixed periodic strategy," IEEE Trans. Instrum. Meas., vol. 65, no. 9, pp. 2067-2077, 2016.

[17] C. Vianello, M. F. Milazzo, and G. Maschio, "Cost-benefit analysis approach for the management of industrial safety in chemical and petrochemical industry," J. Loss Prev. Process Ind., pp. 116-123, Mar. 2019. 